\title{
Editorial
}

\section{Meningkatkan Kesadaran Atas Resistensi Antimikroba di Rumah Sakit, Melalui Standar Akreditasi}

\section{DJONI DARMADJAJA}

\author{
${ }^{1}$ Komisi Akreditasi Rumah Sakit \\ Email korespondensi: djoni@kars.or.id
}

Masalah resistensi antimikroba merupakan masalah kesehatan dunia sehingga WHO menetapkan masalah resistensi ini sebagai satu dari sepuluh ancaman kesehatan global pada tahun 2019, karena mengakibatkan dampak merugikan terhadap kesehatan (WHO, 2019). Selain menurunkan mutu dan keselamatan pasien, masalah resistensi antimikroba juga meningkatkan biaya pelayanan kesehatan.

Resistensi antimikroba ini terjadi di seluruh negara dan berpotensi menyebar tanpa batas serta secara global diperkirakan dapat menyebabkan kematian 10 juta orang pertahun pada tahun 2050. Diperkirakan dari segi biaya resistensi antimikroba akan menghabiskan biaya 100 Triliun dolar (US). Dalam konteks nasional masalah resistensi antimikroba ini juga diperkirakan dapat mengakibatkan kematian sekitar 135.00o pertahun dengan beban biaya 56 Triliun rupiah per tahun (Neill, 2016).

Meningkatnya masalah resistensi antimikroba terjadi akibat penggunaan antimikroba yang tidak bijak dan bertanggung jawab, menyebabkan penyebaran mikroba resisten dari pasien ke lingkungannya. Praktik pengendalian dan pencegahan infeksi belum dilakukan dengan baik. Jadi memang masalah resistensi pada umumnya disebabkan oleh paparan antibiotik yang berlebihan, baik dalam bentuk misuse ataupun overuse.

Masalah dan potensi kerugian yang akan terjadi pada mutu pelayanan kesehatan di Indonesia akibat penggunaan antimikroba yang tidak bijak juga disadari oleh pemerintah di Indonesia, maka Kementerian Kesehatan juga telah mengeluarkan Peraturan Menteri Kesehatan No. 8 tahun 2015 yang mengharuskan rumah sakit menyelengarakan program pengendalian resistensi antimikroba (PPRA). Menindaklanjuti PMK No. 8 tahun 2015 tersebut, Kementerian Kesehatan juga sudah membuat Rencana Aksi Nasional Resistensi Antimikroba yang mengacu pada Global Action Plan WHO yang berisi 5 sasaran strategis sebagai berikut :
Sasaran 1: meningkatkan kesadaran dan pemahaman tentang resistensi antimikroba melalui komunikasi efektif dan pendidikan dan pelatihan

Sasaran 2: memperkuat pengetahuan berbasis bukti melalui surveilans dan riset.

Sasaran 3: menurunkan insidensi infeksi melalui kegiatan Program Pencegahan dan Pengendalian Infeksi dan higiene sanitasi

Sasaran 4: mengoptimalkan penggunaan antimikroba pada manusia dan hewan.

Sasaran 5: mengembangkan upaya ekonomis yang berkelanjutan yang dibutuhkan semua negara, serta investasi dalam penemuan obat baru, alat diagnostik, vaksin dan intervensi lain.

KARS telah memasukkan edisi penyelenggaraan PPRA ini di rumah sakit sebagai standar akreditasi dalam Standar Nasional Akreditasi Rumah Sakit (SNARS) edisi 1 yang diberlakukan sejak 1 Januari 2018. Seluruh rumah sakit yang akan menjalani proses akreditasi, dipersyaratkan melakukan 5 kegiatan pokok dalam standar PPRA yaitu:

1. Peningkatan pemahaman dan kesadaran staf dan pasien serta keluarga akan masalah resistensi antimikroba.

2. Pengendalian penggunaan antibiotik di rumah sakit

3. Surveilans pola penggunaan antibiotik di rumah sakit

4. Surveilans pola resistensi antimikroba di rumah sakit

5. Forum kajian penyakit infeksi terintegrasi

Pada awal, rumah sakit merasa kesulitan mengerjakan penerapan SNARS, karena memerlukan biaya tinggi dan sumber daya khusus yang belum tersedia. Akan tetapi dengan berjalannya waktu, telah terjadi peningkatan pemahaman dan kesadaran staf dan manajemen rumah sakit akan masalah resistensi antimikroba, serta upaya untuk melaksanakan pengendalian penggunaan antibiotik secara bertahap. 
Rumah sakit bahkan terlihat berlomba-lomba membuat alat bantu dan aplikasi untuk mendukung pelaksanaan program PPRA. Salah satunya adalah penerapan program RASPRO, sebagai aplikasi pengendalian penggunaan antibiotik yang dikembangkan oleh salah satu rumah sakit swasta di Jakarta.

Pada edisi kedua ini JHA menyajikan beberapa artikel, diantaranya terkait dengan upaya yang mendukung pelaksanaan PPRA di rumah sakit. Artikel-artikel tersebut mencakup: perubahan perilaku profesional kesehatan, survei program pengendalian resistensi, penerapan lean management untuk menurunkan waktu tunggu pemulangan pasien, perbaikan durasi waktu tunggu layanan, dan modifikasi manajemen risiko pasien rawat inap

\section{Referensi}

Kementerian Kesehatan Republik Indonesia. (2015). Peraturan Menteri Kesehatan Republik Indonesia No. 8 Tahun 2015 Tentang Program Pengendalian Resistensi Antimikroba di Rumah Sakit. Jakarta: Kementerian Kesehatan RI.

Neill JO. (2016). Tackling Drug-Resistant Infections Globally: Final Report and Recommendations - The Review of Antimicrobial Resistance. https://amr-review.org.

World Bank Organization. (2019). Ten Threats to Global Health in 2019. https://www.who.int/emergencies/ten-threats-to-global-healthin-2019. 